\title{
Institutionalizing Social Norms and Legal Culture: Social Dynamics under Legal Awareness Policy in Contemporary China*
}

\author{
Kwong-or Fu \\ School of Law, City University of Hong Kong, Hong Kong, China \\ Email: fukwongor@gmail.com
}

How to cite this paper: Fu, K. O. (2021). Institutionalizing Social Norms and Legal Culture: Social Dynamics under Legal Awareness Policy in Contemporary China. Beijing Law Review, 12, 993-1015. https://doi.org/10.4236/blr.2021.123051

Received: August 1, 2021

Accepted: September 25, 2021

Published: September 28, 2021

Copyright (อ 2021 by author(s) and Scientific Research Publishing Inc. This work is licensed under the Creative Commons Attribution International License (CC BY 4.0).

http://creativecommons.org/licenses/by/4.0/

\section{(c) (i) Open Access}

\begin{abstract}
This paper examines China's policies on legal awareness in mid-2021. It brings into focus the social dynamics of the continuous institutionalization of social norms that are shaping the legal culture in China. It is argued that the discovery of legal culture outweighed the sociocultural imaginations of orders by the institutionalization of social norms. On the utilization of laws, it shows that the utilization of the laws is the direct result of the psychological expectation in seeking Justice via the laws-i.e. the narrower the gap between law-on-the-book and law-in-action, the higher incentives the Chinese citizens resorting disputes to the laws. On enhancing the obedience of the laws, it shows that a powerful discourse would be engineered with the external ideological environment/social norms (values, beliefs, and Zeitgeist of the contemporary Chinese society) such as the political atmosphere of "anti-corruption", "security", and "safety" and the recall of the pure socialist spirit.
\end{abstract}

\section{Keywords}

Legal Awareness, Legal Culture, Legal Discourse, Institutionalization, Social Norms, Social Dynamics, Utilization of the Laws, Obedience of the Laws

\section{Introduction}

In socio-economic studies, scholars often compare China's tremendous achievement after the 1979 Reform and Opening-up policy-in terms of statistical data such as Gross Domestic Product growth rate (Morrison, 2019) - with the first 30 years of the establishment of the People's Republic of China (PRC), and describe

${ }^{\star}$ This Article is amended based on the author's Independent Research program submitted to the affiliated institution. 
the latter period as undertaking a series of "painful reforms to modernize" China's political and economic system in order to create a more "sustainable path to independence and prosperity" (Blanchette, 2019). Such can also be seen in the legal system, scholars in this field often categorize Mao's period as "governed mainly on the basis of Party policy and administrative regulations", whereas the latter period is "governed mainly on the basis of the publicly promulgated laws" (Peerenboom, 2002).

Amid this phenomenal transition of the Chinese society, in 2021, together with the "Rule of Law Construction Plan 2020-2025" (Xinhua, 2021), China's central authorities (Communist Party of China (CPC) Central Committee and the State Council) have released a periodic plan (5-year) to carry out publicity and education to raise public awareness of the law, in a bid to facilitate economic and social development in the $14^{\text {th }}$ Five-Year Plan period (2021-2025), and aims to create a suitable legal environment for fully building a modern socialist China (Xinhua, 2021). The policy intent of which is to "significantly improve legal awareness among the public and law-based social governance", as well as to "build a more integrated system of law education by 2025" (Xinhua, 2021).

These policies had marked China's effort in further institutionalizing its laws and social norms, one may wonder: 1) What are the socio-legal gaps between the institutionalized laws and their actual operations in China? Thus, 2) How do such socio-legal gaps affect the policies impacts of legal awareness enhancement? Also, 3) What does it mean to "enhance" legal awareness, to what extent, and from what aspects? Lastly, 4) What socio-cultural factors affecting Chinese citizens' behaviors and ideological thinking?

Against this backdrop, this paper brings into focus the social dynamics of the institutional transformation of the Chinese society. This paper breaks down the policy intents of the enhancement of legal awareness as (a) enhancing the awareness of utilizing the laws (rights-based), and (b) enhancing the awareness of obeying the laws (duty-based) - and uses the gap analysis in socio-legal studies to examine the possible social dynamics in raising the legal awareness among the Chinese society. It can be roughly divided into the following parts: 1) It begins with the brief introductions of the concept of "legal awareness" and the current directions of academic research in this field; 2) It then explores the social dynamics of legal awareness and the utilization of laws under the lens of "gap-analysis" in socio-legal studies; 3) lastly, it explores the foreseeable social dynamics under the lens of socio-cultural studies, and investigate the formation of the ideological phenomenon and legal culture in Chinese society.

Distinguishing itself from similar studies in this area, this paper analyses the driving factors and incentives instead of the damaging factors of legal awareness enhancement in China. It sees legal awareness as a collective social phenomenon instead of a mere tool of public governance (detailed contributions of this paper are provided in later section). This paper maintains its focuses on the determinative conditions and foreseeable outcomes of the enhancement of legal aware- 
ness in contemporary Chinese society-supplemented by the empirical evidence to exemplify its observations and arguments, covering 1) the concept of Law and Culture by Anthropologists Lawrence Rosen and Clifford Geertz respectively; 2) anti-bribery laws in China, and 3) the formation of the ideology of anti-racism and the laws of anti-discriminations, 4) the IP laws and employment laws in China; 5) the concept of "Soft Power" as developed by Political Scientist Joseph Nye; 6) the comparative studies of Singapore's and Malaysia's anti-corruption laws; 7) Criminal Laws of the People's Republic of China; and 8) Sociologist Eugen Ehrlich's observations on social norms and the laws.

At last, it must be acknowledged that there is the doctrinal disparity between the Western model of Rule of Law and China's (Lawrence \& Patterson, 2018) that is arbitrary to be ignored-some scholars attributed China's legal system as “Rule by Law" or "Political-legal system" (zhengfa xitong 政法系统) (Wang \& Liu, 2019) as distinguished from the Western model of Rule of Law-but admittedly, the focuses of this paper are to examine the socio-legal effects of China's public policy on the legal system to the Chinese society in large-as well as the foreseeable social dynamics occurring amid the Chinese authorities' effort in raising the society's legal awareness-thus, such doctrinal disparity would be understood in this paper as the differences in the interpretation between two socio-legal-political apparatus of the Western and China's.

\section{The Academic Concept of Legal Awareness and Its Current Perceptions in China}

\subsection{Concept of Legal Awareness}

Legal awareness often refers to the awareness and attitudes of the general public towards laws and legal institutions (Zariski, 2014). It is closely connected with the concept of legal consciousness (Zariski, 2014). There are factors affecting the formation of legal awareness, including public legal education, legal culture, and other psychological and ideological elements that carry meanings to the behavior of the individual (Kozhukhova \& Zhiyenbayev, 2018). Legal awareness also being closely connected with legal psychology, which is identified as a complex structural formation of the rational components (Kozhukhova \& Zhiyenbayev, 2018). For some scholars, legal awareness would not occur as a "sociocultural vacuum" but always takes place in a rich social and regulatory, legal, and political environment (Andreeva et al., 2019).

All in all, placing the concept of "legal awareness/consciousness" under the lens of a systemic tool to understand the collective behavior of the society and its patterns, the concept can be summarised into the following two streams: 1) From the Top-down perspective, the concept emphasized on the obedience and respect of the laws. As such, it can be perceived as closely related to the dynamics of public governance within the society (Marshall \& Barclay, 2003); 2) From the Bottom-up perspective, the concept emphasized the utilization of the legal system as a tool of dispute resolution. As such, it can be perceived as one of the 
social norms among society (Ewick \& Patricia, 1998) ${ }^{1}$.

\subsection{Current Position of the Concept in Asia and China}

In the field of empirical academic studies, scholars in China and other Asian regions are studying legal awareness from multiple perspectives, including: 1) From the perspective of the interaction of law and "qing" (情) ${ }^{2}$ in shaping the legal consciousness of the Chinese society (Liu, 2018) - in fact, this type of research is the mainstream academic research in the fields of the transplantation of laws, and harmonizing Chinese laws with foreign laws (DiMatteo, 2018), namely, examining how the perceptions of law in Chinese society are being shaped by traditional/classical Chinese values and conceptions (though these types of research would not manifestly mention the concept of "legal awareness/consciousness" in their discussions) (Xu, 2015); 2) Studying the influences of colonial architecture and judicial iconography on the legal consciousness of the court personnel in India (Khorakiwala, 2018); 3) Examining the Thai legal consciousness of the perception that judges have an exalted status entitling them to make broad-ranging pronouncements about the social and political issues (Somanawat, 2018); 4) studying legal consciousness of the protection of intellectual property (IP) in China (Su, 2018); 5) Studying how morality and legal awareness are shaping the labour laws in Vietnam (Nguten, 2018); 6) Studying the roles of pedagogical tools in the formation of anti-corruption legal awareness in educational institutions (Sarayev et al., 2019); 7) Analyzing the factors affecting the legal awareness of an individual and identify the essential characteristics of cognition in a digital society (Laptev \& Fedin, 2020). In China, apart from the emphasis of the official media that the Chinese society should maintain a great degree of legal awareness (Liu, 2018), some officials had commented on the lack of legal awareness of some financial practitioners in China (Xinhua, 2020). Academic works in China-including court reports (Shanxi Fenyang City People's Procuratorate, 2019)_ however, focus on the enhancement of legal awareness among the younger generations in China, especially University students (Ma, 2018) and college pupils (Luo, 2018) or the enhancement of legal awareness among the migrant workers in China regarding their labor protections (Chan, 2015) and dispute resolutions $(\mathrm{Hu}, 2020)(\mathrm{Na}, 2009)$.

The common features of the above empirical studies are their emphasis on the factors that damaged the formation of legal awareness-e.g. in the studies of how traditional values shaped the Chinese citizens' perception of law, and how thoughts in the colonial times influenced the judicial personnel's perception of the laws, etc. Such an understanding implies hidden conflicts between the social norms and the institutionalized laws, which sometimes are covered with a thick

${ }^{1}$ Apart from these, the definitions and defining factors of 'legal awareness' would be mentioned and revisited throughout the whole paper.

${ }^{2}$ A traditional social concept in China which can be translated as contextual "feelings" and "emotions" towards a person or situation. The concept often occurs with fa (法) (law), such as the swing between emphasizing the defendant or adopting stringent laws. 
atmosphere of universality and the predomination of values. These sorts of ideologies are drawn upon the universalism of certain principles and laws and are considered by some researchers as the collective reflection of Western (legal) culture (Jouannet, 2007). On the other hand, much of the literature considers legal awareness enhancement as a tool to tackle il/legal problems such as the violations of regulations and criminal activities-e.g. a) the studies on the legal awareness of the Chinese youth often considered that legal awareness is a tool to control the behavior of the youth, b) how raising legal awareness can tackle the problems of IP protections in China, and c) how legal awareness would transform the behaviors in the digital society. These sorts of arguments represented the socio-engineering of a "better" society by ways of public policies and public interventions, by so framing the legal culture and legal ideology in a thick political atmosphere (Charny, 1999).

This paper thus distinguishes the current research from the above by breaking down the concept of legal awareness as a) the utilization of laws, and b) the obedience of laws, thus analyze the driving factors and incentives instead of the damaging factors of legal awareness enhancement in China-in other words, shows a) the reliability of the legal system as a factor fostering legal awareness among the Chinese society (by socio-legal gap analysis), and b) the socio-cultural constructions of ideologies that maintain awareness of the laws among the Chinese society (by socio-cultural analysis). Also, it shows that legal awareness is a collective and continuing social phenomenon requiring the observers to investigate the underlying combinations of social norms and hidden/manifesting ideologies, instead of perceiving it as a mere tool of public governance (liberalist observers often consider public policies and governmental interventions as a form of oppressions/manipulations but neglected the hidden social norms and the operations of ideologies which represented a dynamical/two-sided power-relation).

\section{Social Dynamics 1: Legal Awareness and Utilization of Laws as a Result of Closing the Socio-Legal Gaps}

"It is not the consciousness of men that determines their existence, but their social existence that determines their consciousness"

- Karl Marx (Marx, n.d.)

In the textual content, the public policies of legal awareness enhancement in China provided a limited scope of the procedures and approaches in raising the collective legal awareness of the Chinese society but only the general directions and the emphasis on educational campaigns. In spite of that-regarding the policy intent of raising the awareness of utilizing the laws (the policy intent of the obedience of the laws will be analyzed in-depth in the coming section)-the following section shows the inter-relational dynamics between the utilization of the laws and the socio-legal gaps in the Chinese society. Even though "legal awareness" is an intangible social consciousness, it is largely dependent on the actual 
existence and functions of the legal system-The narrower the gap between law on the book and law in action, the higher the incentives of Chinese citizens resorting to civil disputes to the legal system, i.e., "Resorting problems to Law, solving problems by Law, solving conflicts by Law"3. By showing that the consciousness and attitude towards the legal system have much to do with its actual functioning-whether the Chinese citizen can feel that "Justice can be expected"4-it unmasks the social dynamics of raising the legal awareness in contemporary Chinese society in this section.

\subsection{Institutionalization of the Legal System and the Socio-Legal Gaps}

The institutionalization of laws and social norms has been a prolonged strategy in the past decades in China (Peerenboom, 2002). But what does it mean when one says that there is "institutionalization" of a system (as argued by some commentators) (Peerenboom, 2002)? For some political scientists, "institutionalization" is the development of a regularized system of policymaking (McGuire, 2004). It is the routines/standard ways/standard procedures developed by the political community which the political actors make references to when making actions to provide a public good (McGuire, 2004). On the basis of the institutionalization of the society, there would be procedures and informal norms that enable the political actors, including a legislature, an administrative agency, or a court, to exercise their powers (McGuire, 2004). As such, in the sphere of legal institutions, institutionalization would mean that there are sufficient procedures and guidelines that the judicial decision-makers and other stakeholders (e.g. The courts, lawyers, prosecutors, etc.) to take part in. Indeed, coined by some legal scholars, the term "Legal Institutionalism"-in the area of socio-economic legal studies-refers to the legally grounded approaches to the institutional and economic analysis of capitalism, and they argued that law involves an institutionalized judiciary and a legislative apparatus because there is a qualitative difference between customs and laws (Deakin et al., 2016). Thus, in the context of the development of China's legal system, as distinguished from arbitrary power, propaganda, and coercion, it is evident that the construction of Rule of Law in China is on the road of "institutionalization", such as to "achieve scientific and completed unification of legal norms", and that "the operation of power is effectively checked and supervised"

All in all, informal/customary rules are considered to be associated with "politico-economic underdevelopment" (Deakin et al., 2016) or "failings or remoteness of the state legal system" (Deakin et al., 2016), whereas formal laws and procedures, and the institutionalization of the legal system are considered to be "progressive" in nature. It is undeniable that formal procedures within the legal

${ }^{3}$ Under section 2 of the legal awareness plan.

${ }^{4}$ At section 3 subsection 2 of the legal awareness enhancement plan.

${ }^{5}$ Overall Goals of "Rule of Law Construction Plan 2020-2025".

${ }^{6}$ Overall Goals of "Rule of Law Construction Plan 2020-2025”. 
system and well-structured legal rules are critically important for the sake of certainties and the smooth operations of the public administration, including the promulgation of laws and public policy.

Yet, given the complex relationship between the uncertainty of human behaviors and the institutionalized norms-i.e. the codified laws in Civil Law and the statutes and Case Law in Common Law-what ties the society's collective behavioral patterns and the institutionalized laws becomes a central concern. Thus, the "Gap Analysis" in socio-legal studies becomes a useful tool for the analysis of China's construction of Rule of Law and legal awareness.

The so-called "Gap Analysis" is a methodology that focuses on the gaps between the laws and everyday lives (Feenan et al., 2013). To the most simplistic elaboration of such concept, it is the analysis of the gaps between "the law in the books"/"formal positive state law" and "the law in action"/"its interpretation and selective implementation in practice” (Hirsch \& Lang, 2018). It can also be about the gaps between the laws and the power of laws and legal techniques (Feenan et. al., 2013). For the anthropologists of law, gap-analysis is also a useful tool for them to "reveal gaps between what people say and what they do" by using "rich ethnographic material to analyze laws, legal processes and understandings in ways that may not occur to a researcher who sets out to test a theory" (Hirsch \& Lang, 2018). What is more important for some scholars in this area is to study the strategies or social dynamics that eventually narrow down or close such gap in advance (Hirsch \& Lang, 2018)—or to imagine a gapless system of rules governing all "conceivable fact situations" (Hirsch \& Lang, 2018). The coming subsection would show the actual applications of the methodology and its relevance to the current research.

\subsection{Socio-Legal Gaps in the Chinese Society}

While Chinese authorities are attempting to formulate its own model and theory of the legal system after decade-long of legal transplantation ( Fu, 2020), the effects of the black-letter laws and their attached awareness among the societies are attracting challenges and being examined in the academic field. In Divorce in China: Institutional Constraints and Gendered Outcomes (by Professor Xin $\mathrm{He}$ at the University of Hong Kong), the central research question was "Why are women still at a disadvantage in Chinese divorce courts?” (He, 2021). Prof. He pointed out that the increasing gender consciousness in Chinese society and a trove of legislation to protect women are not as sufficient as they may seem in tackling gender bias and the disadvantages facing Chinese women today. Based upon the gap analysis, the following subsection shows that the policies of China's Rule of Law Construction Plan and the legal awareness enhancement plan may create other gaps in its actual operations-exactly due to the socio-legal gaps in the Chinese society, the Chinese citizen is reluctant to resort their disputes to the legal system, thus lower their legal awareness/consciousness in the longer term. 


\subsubsection{Socio-Legal Gaps in the Chinese Society: Intellectual Property Protection}

In the area of intellectual property (IP) laws, numerous laws on the protection of IP in China had been promulgated or revised in recent years: 1) The Trademark Law of the People's Republic of China had been amended by the Standing Committee of the National People's Congress (NPCSC) in 2019 in a bid to prohibit bad-faith trademarks fillings which took effect on $1^{\text {st }}$ November 2019 (Baker McKenzie Client Alert, 2019)-Inter alia, at para. 4 of the Trademark Law, it has been amended that "applications made in bad-faith for trademark registrations that are not intended for use shall be rejected"; 2) The Patent Law had been amended in 2020 which codifies changes for pharmaceutical-related patents, including the introduction of a patent linkage system in China to align with the international practice (Jones Day White Paper, 2020); 3) The Copyright Law had been amended in 2020 to amend the penalties in cases of copyright infringement, and the increased power of the authorities in investigating illegal acts (Baruzzi, 2021); 4) “Trademark Infringement Judgement Standard" released by the State Council (Glueck, 2020); 5) "Opinions on Strengthening the Protection of the Intellectual Property Rights" released by the State Council (Glueck, 2020). It is undeniable that there is an increase in high-profile IP litigations in China in recants years, e.g. Seiko was awarded RMB 10 Million by Guangzhou Court in an IP infringement case in late 2020 (Yeung, 2021).

Yet, for smaller claim IP infringement or Chinese citizens and cooperation with lesser resources in hand, they may not be able to resort their disputes to the legal system due to a number of obstacles (Hou et al., 2020)-e.g. a) the conservative approach taken by the authorities towards unfair competition cases due to the relatively weak legal IP knowledge of the officers responsible; $b$ ) the ambiguous procedures in pursuing Police enforcement power by filling the infringement as criminal cases, a usual practice has been identified where the Police did not decide to pursue a case without notifying the IP rights holders in advance; which, in turn, increased the incentives of IP infringement in China as the deterrence effects are insufficient. Therefore, lowering the utilization of the laws in China.

\subsubsection{Socio-Legal Gaps in the Chinese Society: Employment Law}

According to Dr. Chen Jingyuan's studies on flexible employment in China, it is found that since the COVID-19 pandemic had affected the chain of socioeconomic operations in China, the number of flexible employments had been increased in the Chinese society covering service industries such as medical care, education, and the takeaway delivery (Chen, 2021). Such a trend of flexible employment imposed weak employment protections on the workers and much lesser occupational benefits are provided for the workers, thus creating a gap between the existing employment protection laws and the rights of these workers in China (Chen, 2021). Such socio-legal gap manifests itself in two ways-on the one hand, the Chinese employment laws provided that only if the labors are 
identified as "employees", they cannot otherwise enjoy "the rights of dismissal protection, labor remuneration, reset and vacation, occupational safety, and health protection, vocational training, collective bargaining, basic social insurance, and labor dispute resolution procedure granted by law" (Chen, 2021); on the other hand, there is no conceptual definition of "flexible workers" either in the Employment Promotion Law of the PRC or the Social Insurance Law of the PRC (Chen, 2021) - thus leaving this area of employment protection blank. Even though the Chinese authorities issued the Opinions on Supporting Flexible Employment through Multiple Channels on 28 July 2020 (Chen, 2021), the limited scope of the definition of flexible workers and their limited protection still impose burdens for the Chinese citizens to resort their civil disputes, if any, to the Chinese legal system - in turn, lower their utilization of the laws.

\subsection{Implications to Legal Awareness Enhancement in China}

The above sub-session shows that for the purposes of enhancing the Chinese citizens' awareness and incentives to utilize the laws in China, the focuses should be on raising the Chinese citizens' expectations of seeking Justice via the laws-by ways of closing the gaps between the laws and social realities in China. With the limited scope, the above examples are only two of the many obstacles that the Chinese citizens would not resort their disputes to the legal system as they often find the outcomes of which unsatisfactory. The last remark in this section is that even though there are signs that the Chinese authorities are satisfactorily tackling high-profile disputes, in order to enhance the utilization of the laws, small-to-middle claims and low-profile disputes should be its true manifestation of legal awareness enhancement. Thus, the process of institutionalizing social norms requires not only the creation of formal laws and regulations but also the smooth operations of the legal system which brings substantial changes to the society at large.

\section{Social Dynamics 2: Legal Awareness and the Obedience of the Laws from Ideological Factors}

"What is soft power? It is the ability to get what you want through attraction rather than coercion or payments. It arises from the attractiveness of a country's culture, political ideals, and policies."

-Joseph Nye (Nye, 2004)

According to Joseph Nye-the distinguished Political Scientist at Harvard University who popularized the concept of "Soft Power" - "Soft Power" refers to "cultural and ideological product of attraction" that "acquires the favorable outcome not by forceable measures but by attractions" (Nye, 2004). Soft power is also to a large degree depending on the power of persuasion of the information (Nye, 2004), it also aims to reach the outcome by attraction but not forceable means or duress (Nye, 2004). On this basis, this paper links the concept of legal awareness to the idea of "soft power"-as both of which concerns the voluntari- 
ness of the collective behaviors of a group of individuals-and therefore rejects the simple conclusion that the Chinese citizens are under the legal awareness to obey the laws only because of its deterrent effects. Indeed, section 29 of the Rule of Law Construction Plan also provides that the Chinese authorities aim to build a theoretical and discourse system of the rule of law that "reflects the socialist nature of China and has distinctive Chinese characteristics, practical characteristics and characteristics of the times".

This section thus attempts to search for any ideological reasoning behind the collective obedience of the laws in contemporary Chinese society. Also, it does not intend to presume that the ideological factors mentioned would be influencing all members of the society-there may as well be other factors unknown to the observers-but only to offer the possible explanations of the interactions between the obedience of the laws and such ideological factors/social phenomenon. The core observations again are the facts that ideological conflicts would damage the smooth operations and obedience of the laws-for the disobedience of the laws, there must be ideological conflicts at large. Fundamentally, legal awareness matters not only the "actions" of the Chinese citizens but their collective "perceptions" towards the laws. Thus, any observer of the legal culture in contemporary Chinese society must ask: How the Chinese society constituted such an ideology that caused great impacts on different groups/entities of the Chinese society? Rhetorically, what are the subtle lines of thoughts at the bottom of the hearts of the Chinese people that would lead them to combine the laws with their daily lives-i.e. "observe traffic rules, develop garbage sorting habits, stop wasting food and drink, and other daily behaviors, raising awareness of rules"7?

\subsection{A Brief Explanation of the Use of the Term "Ideology"}

This paper does not intend to use the term "ideology" with the inherited conception developed by Marx and Engel, which provides that ideology is "to maintain the hegemony of the ruling class by legitimating the dominant mode of production, institutions, and values" (Kellner, 1981). Instead, the term "ideology" more adheres to Anthropologist Clifford Geertz's understanding of the concept of culture which denotes the meaning of "a system of inherited conceptions expressed in symbolic forms by means of which men communicate, perpetuate, and develop their knowledge about and attitudes toward life" (LaCapra, 1988). It also examines the relationship between cultures and its influences on the laws. In the studies of socio-cultural studies, socio-cultural phenomena can be in the forms of fashion, style or ideology, etc. (Krause, 2019), whereas culture can also be divided as official cultures ("refers to culture that is actively shaped or at least influenced by the state") (LaCapra, 1988), high or elite culture ("refers to the artifacts and the general culture (or discursive practices) of elites in the arts and science”) (LaCapra, 1988), mass culture ("evokes the image of large numbers of

${ }^{7}$ At section 3 subsection 2 of the legal awareness enhancement plan. 
people who do not form face-to-face publics but rather audiences of spectators or more or less organized crowds of participants in events such as rallies and parades") (LaCapra, 1988), and popular culture (LaCapra, 1988). Another concept which this paper intends to use is "Zeitgeist" which denotes the meaning of "a hypothesis for a pattern in meaningful practices that is specific to a particular historical time-period, links different realms of social life, and extends across geographical contexts" (Krause, 2019).

\subsection{The Relationship between Law and External Ideological Environment}

"If culture is by definition constitutive, so too must law be formative and not simply formed"

- Lawrence Rosen (Rosen, 2006)

According to Anthropologist Lawrence Rosen, he categorized law as constituted by culture, and culture (in no small way) constituted by law-a very common perception on the nature of laws among anthropologists (Rosen, 2006). For Rosen, there are distinctive history, terminology, and personnel of the law itself, but the laws do not exist in isolation (Rosen, 2006). From such perspective, Law carries not only different functions but also multiple socio-representations: 1) a mechanism for dispute resolution or decisions enforcements, 2) "articulated rules or as differential power", 3) "the reification of personal values or superordinate beliefs", 4) a framework for ordered relationships dependent on its "attachment to all the other realms of its adherents' lives" (Rosen, 2006). As such, even though the overwhelmingly value-oriented informal pressure are not commonly seen in all societies-it is suggested by some anthropologists, based on their empirical studies, that among religiously oriented groups in some regions, the informal public opinion are outweighing the formal rules (or laws) (Rosen, 2006)-laws itself are the untouchable ties that connect all members of the society upon common cultures. As suggested by Anthropologist Clifford Geertz, to conceive law "as a species of social imagination", or "the vehicle for keeping society functioning” (Rosen, 2006).

In fact, in the area of socio-economic legal studies, the law does not only represent the power relations within the society but as a "constitutive part" of the "institutionalized power structure" (Deakin et al., 2016). Yet, a hegemonial and delusionary vision often occurs on the relationship between social development and the legal discourse that laws are "powerful" in terms of their utilization in fighting for "social justice" (Eliasson, 2015) and reshaping the social reality (Nieto, 2015). Nevertheless, such a vision is more like putting the cart before the horse as it has neglected the relational effects between laws and the social context to which it applies. The following would exemplify the above lines of arguments from a comparative law perspective: 1) in terms of anti-corruption laws, Singapore and Malaysia are two distinguishable examples. Notwithstanding the fact

${ }^{8}$ A German word, “Spirit of the age” in English and “时代精神” in Chinese. 
that they are geographically proximate, and that both of which are originated from the Common Law tradition and adopted several similar anti-corruption laws (Ng \& Jacobson, 2017), Singapore became one of the well-recognized "paradise" of zero-corruption rate (Ong, 2021) while Malaysia is still on the road to combating corruption (Shankar, 2020). Formalist observers may resort solely to the effects of the "hard"/"strict" law of Singapore (The Agency against Corruption (Taiwan, China), 2013), yet, neglected the fact that Malaysia also has a similar historical and cultural background as Singapore ${ }^{9}$ but manifested fairly different socio-legal effects between these two societies in terms of their anti-corruption laws (Unknown (Reuters, 2018)). Alternatively, there are unneglectable ideological factors that can explain such differences, i.e., the theory and practice of pragmatism which has been continuously developed and maintained by Singapore's one-party dominant state (Tan, 2012) (according to Professor Kenneth Paul Tan of the University of Hong Kong, though the country often disguise its ideological work and political nature through an absence of ideology and politics) (Tan, 2012) and, in turn, the rhetoric of pragmatism helped to maintain the society's awareness and consciousness of obeying the laws and resort to the laws in resolving disputes-paradoxically, the low-corruption rate implies that anti-corruption laws in Singapore are rarely applied nowadays, (Lau, 2021) and that her "hard"/"strict" laws represented the society's pragmatic ideology; 2) Also, taking the most significant fight for social justice over the past decades-the fight against racism—as an example, sociologists found that there was massive research conducted by scholars including Max Weber and the adoption of his thoughts, W. E. B. Du Bois, and Gunnar Myrdal (Araújo \& Maeso, 2014) during the period of 1890 to 1940 in Europe, which had a huge impact on shaping the dominant understandings of race relations by elucidating the anthropological differences between ethnic groups (Araújo \& Maeso, 2014). Such research reproduced the discourse of anti-racism and had also entered the sphere of public administration and policy intervention against racism (Araújo \& Maeso, 2014). As a result, such public discourse of anti-racism, combined with the rise of evidence-based policy framing, then reproduced the political rhetoric of the laws and policy against race discrimination in Europe and projected its influences around the globe (Araújo \& Maeso, 2014).

Based upon the above, it shows that the social consciousness towards any particular ideologies residing in the society would become the flourishing soil for the actual operations of the laws as this is the basis of its smooth operations-laws became the structural product of social development. In the current studies, i.e. in the context of China's construction of Rule of Law and legal awareness enhancement, observers must pay close attention to whether the external ideological environment (e.g. China's model of Authoritarian Ideology) (Liu et al., 2021) has been fully cultivated, or else the legal awareness enhancement plan would result in a larger gap between the policy intent and the opera${ }^{9}$ In terms of their ethnic culture and colonial history, Singapore was also part of Malaysia before gaining its independence in 1965. 
tion of the policy. The successful combination of the laws and external ideological environment would then create a powerful discourse which would un-/consciously shape the behaviors of the social actors in that social field-see 1) the rise of anti-racism and the flux of anti-discrimination laws around the globe in recent decades (Hunt, 2012), as well as the 2) Western-led hegemonial discourse of "Human-rights" and the flux of human rights laws after the second world war till today (Douzinas, 2000). Upon this, the next subsection shows the relationship between ideological factors and motivation of legal awareness.

\subsection{Ideological Factors Motivating Legal Awareness}

Some scholars suggested that legal awareness is one of the ways that humans perceive reality (Laptev \& Fedin, 2020). For Leon Petraźycki-a Polish Philosopher specializing in the sociology of law-legal awareness is the "imperative-attributive nature of one's awareness of legal duty" with "certain motivational force" (Laptev \& Fedin, 2020). Can such a "motivational force" be the ideological factor? According to Sociologist of law Eugen Ehrlich, there are the "norms of decision" which determine the actual behavior of the individuals (Bodenheimer, 1974). There are different motives for which a person voluntarily performs his/her duties without the threat of compulsion by the state or the laws themselves (Bodenheimer, 1974). Ehrlich also suggested that the performance of legal duties is less a matter of conscious thinking but more of an unconscious habitual activity (Bodenheimer, 1974).

Such an understanding of a person's behavior of legal performance has great implications to the current studies: 1) On the one hand, it helps to understand that an effective construction/formulation of legal awareness should have the individual performing his/her legal duties without the conscious thinking of his/her-for example, it goes without saying that one has to pay for the item he/she picked up before he/she lefts the shopping mall, it does not require much conscious thinking for an ordinary person to consider it as lawful/unlawful in doing so. Such is the real operations of legal awareness among the society. This can also be seen as one of the policy intents of the legal awareness enhancement plan of China-see section 3, subsection 2 of China's legal awareness enhancement $\operatorname{plan}^{10} ; 2$ ) On the other hand, ideological factors can motivate legal awareness. For example, in an interview dated 1965, Singapore's founding father Lee Kuan Yew told the journalist that an American Central Intelligence Agency (CIA) agent once tried to bribe a Singapore official in the 1960s, but the official did not accept the bribery and reported such incident to the Singaporean state ${ }^{11}$. Even though it may be arbitrary to overestimate the motives of the Singapore official, it is objectively evident that the ideological work in the early days of the establishment of Singapore-e.g. the ideology of "politics of survival", Confucianisation, Asianisation,

${ }^{10}$ It also provides that starting from daily life behaviors such as obeying traffic rules, cultivating habits of garbage classification and stopping food and beverage waste, the authorities would raise awareness of rules so that the people can develop law-abiding habits in practice.

${ }^{11}$ https://www.youtube.com/watch?v=142FbTYeK7k. 
civic-religious, etc. Lee Kuan Yew once said the following: "It's because we don't have oil and gas and they know that we don't have, and they know that this progress comes from their efforts. So please do it and do it well' (Tan, 2012)-had amply constructed the ideological factors that motivated the legal awareness of the official.

\subsection{Ideological Factors Motivating Legal Awareness in China}

There are two significances of the above: 1 ) it proves that China's Rule of Law Construction Plan and the legal awareness enhancement plan will only have little actual effect to the Chinese society if there lacks the well-cultivated external ideological environment to support its internal transformation-which significantly influence the internal rationality of the laws; and 2) it shows that ideological factors can be the motivational force of raising the collective legal awareness of the society. From a Foucaultian perspective, "discourse" is not the textual and verbal communications between different social actors but is also the representation of the power relations in a wider social structure (Powers, 2007). As a result, discourse analysis involves the examinations of the fundamental philosophical basis of which the language is being shaped and formulated, a discourse is never simply a linguistic representation of what the "speaker" is saying, but a diffuse representation of his/her thoughts, ideologies and beliefs (Willig \& Rogers, 2017). Also, according to the Frankfurt school of critical social theories, there are no one-sided interpretations of a single discourse but a number of preferable interpretations-as a result, it opens the tunnel for different interpretations of the same discourses under multiple lenses which ultimately provide a bunch of different identifications of values (Powers, 2007). As such, a powerful discourse of legal awareness would be engineered, which, in turn, pushes the social actors within that field to behave, think, and perform their duties under the discourses-obeying the laws is no longer a mere or random action but overlapped with a layer of meanings-values, beliefs, and Zeitgeist, as shown in Figure 1.

\subsubsection{The Political Atmosphere of Anti-Corruption as a Driver of the Obedience of the Laws}

In the context of China's Construction of Rule of Law and the enhancement of legal awareness, in regard to public administration and anti-corruption, the Rule of Law Construction Plan provides that it aims to "Build a government governance system with clear responsibilities and administration according to the

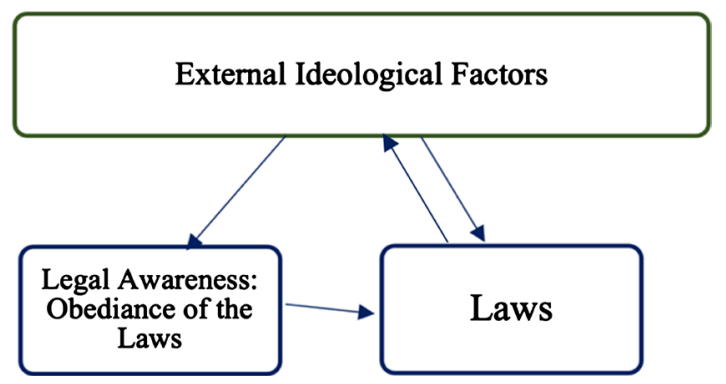

Figure 1. Correlational Relationship between Laws, Ideology and Legal Awareness. 
law" (Section 11), "Strictly implement the system of major administrative decision-making procedures to effectively prevent illegal decision-making, improper decision-making, delayed decision-making" (Section 11) ${ }^{12}$, and "The operation of power is effectively checked and supervised" (the third Overall Objectives). The legal awareness enhancement plan also provides that it aims to "Promote the maintenance of social justice in accordance with the law, and promote the modernization of the national governance system and governance capacity on the track of the rule of law" (Section 1, subsection 2). These lines of policy directions can be seen as complying with the ideology of anti-corruption in recent years as maintained by the Chinese authorities through the massive anti-corruption campaign since 2013, where nearly three million government officials are laid off and/or prosecuted against corruption-related crimes in China (Diallo, 2021) according to the Supreme People's Court Report in 2019, 28,000 graft cases involving embezzlement, bribery, and dereliction of duty are concluded, which involved 33,000 people, including 18 former officials at provincial-level and above, former higher-ranking officials; 2466 people were convicted of offering bribes, 1064 court staff investigated and punished for abusing the power of their positions (Shi, 2019). This political atmosphere-similar to that of Singapore's (see the example in the sub-sessions above) (Tan, 2012)-shows that the Construction of Rule of Law policy is more or less its ideological product, and in return, the policy had restrengthened such political atmosphere in the longer term-to "rescue" the declining trust and legitimacy of the Chinese authorities' governance (Chawala, 2019). What is more relevant to the current research is that, according to some commentators, similar anti-corruption crackdowns had been conducted several times by the Chinese authorities but the effects of which are far-weaker than the one occurred in recent years-not only does the number of officials being laid-off is much higher, the sonority and ranking of the officials are also much higher (Diallo, 2021). As a result, regardless of the driving factors behind such anti-corruption campaign in China-some Western commentators considered the campaign as an opportunity of sidelining elements that could challenge the authority of the top leadership (Diallo, 2021) - an atmosphere/ ideologies of anti-corruption and accountable public administration had been eventually engineered in China, which can, in turn, foster the obedience and compliance to the laws by the Chinese officials-one of the ripple effects of legal awareness and consciousness among the Chinese society. For those officials and citizens who believe in these values of the political atmosphere, it thus provides them with ideological support to obey the laws in China.

Such a political atmosphere of anti-corruption in China also has a great amount of associated explanation with behavioral economics-i.e. The effect of loss aversion. Loss aversion can be understood as the effects of which an individual would feel more "painful" for their current losses than their future gains,

${ }^{12}$ Original wordings: Strictly implement the system of major administrative decision-making procedures to effectively prevent illegal decision-making, improper decision-making, delayed decision-making. 
and that is the psychological factors closely connected with the endowment effects and status quo bias-all in all, it suggests that "losses loom larger than gains" (Gal et al., 2018). From such a perspective, the Chinese officials who climbed to the top ladder of the political power hierarchy would not easily risk their reputations and the social status they gained during the past decades, and therefore behave themselves as more adhered to the standard of integrity provided by the anti-corruption campaign in China. In other words, even though corruptions may gain them great monetary benefits and "buys" them intangible benefits (e.g. connections with the corporations/individuals who bribed them)-for the experienced officials who committed corruption to a certain degree in China-theoretically they would no longer continue their acts of corruption, for the fact that they cannot afford to lose their current socio-status as a high-rank government official in China. This, in turn, shows that they would obey the laws and maintain a degree of legal awareness not because that it can increase their future monetary gains but that they are afraid of losing the current gains-in fact, it is suggested by some commentators that the Chinese officials are "increasingly reluctant to perform their duties" (Diallo, 2021), which can alternatively support the observations on corruption and loss aversion from the above.

\subsubsection{The Political Atmosphere of "Security" /"Safety" as a Driver of the Obedience of the Laws}

Section 2, subsection 5 of the legal enhancement plan, provides that it aims to "adapt to the need for integrated development and security, vigorously promote the overall national security concept and national security law, anti-secession law, national defense law, anti-terrorism law, biosecurity law, network security law, etc., and organize the " 4 - 15" National Security Education Day, promote national security awareness and risk prevention and control activities." Also, "to adapt to the need for a higher level of peace in China, continue to strengthen publicity and education on criminal law, criminal procedure law, law on public security management punishment, etc., to promote punishment and crime prevention in accordance with the law." Further, "focusing on the construction of ecological civilization, food and drug safety, the elimination of evil, drug prevention, community management services, building harmonious labor relations, prevention and control of domestic violence".

It is not difficult to see that the common subject in these lines of policy directions of legal awareness enhancement is "security". In fact, safety and security are two main characteristics of the governance model as upheld by the Chinese authorities, which provides that a powerful central government can efficiently foster the development of the society and offer the safety net of security (Lai, 2016). For the Chinese citizens, obedience to the laws thus added on another meaning-an exchange for an efficient system of public governance that can prove itself as a viable alternative to the Western model (China Daily, 2018). For those citizens who find it convincing, it thus offers ideological support for their obedience to the laws in China. For example, during the COVID-19 pandemic, 
the Chinese citizens greatly incorporated and obeyed the stringent anti-virus measures-which is also governed by law and regarded as crimes of disrupting public order (e.g. Article 277 of the Criminal law of the PRC) $)^{13}$ - under the mass control of the Chinese government for an exchange of "health safety" and "public security" ( $\mathrm{Wu}, 2020)$ - a sharp difference from the same situation as in the Western jurisdictions where anti-virus measures are considered by some as an infringement of liberty and personal freedom, thus rejected to obey the related laws of anti-virus measures (BBC, 2020).

\subsubsection{The Collective Rewind of the Socialist Spirit in China}

In mid-2021, the official Weibo account of Tsinghua University Library revealed that Selected Works of Mao Zedong has been ranked first among the library's book lending list (HK01, 2021). Nearly at the same time, young Chinese netizens are reminiscing about Mao Zedong on $Z h i-h u^{14}$ and Bilibili $I^{15}$. Adopting the concept of "Zeitgeis"16 - which denotes the meaning of "meaningful practices that are specific to a particular historical time-period, links different realms of social life, and extends across geographical contexts" (Krause, 2019)—the recall of the pure socialist spirit in the Chinese society in recent years reflects that there is an ideological consensus among some of the youngsters in the Chinese society. In fact, a typical claim with regard to criminology is that, under Communist rulings, a great deal of crime would be eliminated because it is believed that inequalities of wealth and power and life-chances-and-poverty would be eliminated, thus, eliminating the root cause and the criminal acts itself (Cowling, 2008). Regardless of the possibility of shaping such a society in reality-for sure the saying that Communist ruling eliminates crimes faces criticism from a wide range of scholars (Cowling, 2008) - the facts that, unlike being attracted by Anarchism, such ideology pervading among the communities of the Chinese young generations would foster their obedience of the laws to a certain extent. It can also be understood under the lens of behavioral economics, which provides that there can be "social preference"-rather than mere calculations of costsbenefits-of which the individuals would not only focus on their own personal benefit - as a contrast to neoclassical economics where it is presumed that human beings are highly selfish in their behavior and decision-making-thus the youth who are attached to the socialist values, such as equality (Gabriel, n.d.) would morally being affectionate with others, and having a lowered desire to ${ }^{13}$ Article 277 of the Criminal Law of the PRC provides the following: "Whoever uses violence or threat to obstruct state personnel from discharging their duties is to be sentenced to not more than three years of fixed-term imprisonment, criminal detention, or control; or a sentence of a fine. Whoever uses violence or threats to obstruct National People's Congress deputies, or local people's congress deputies, from discharging their lawful deputy duties is to be punished according to the preceding paragraph. Whoever, in the event of a natural disaster or an emergency, uses violence or threats to obstruct Red Cross personnel from discharging their lawful responsibilities is to be punished according to the first paragraph."

${ }^{14} \mathrm{~A}$ question-and-answer website.

${ }^{15} \mathrm{~A}$ video-sharing website.

${ }^{16}$ A German word, “Spirit of the age” in English and “时代精神” in Chinese. 
commit crimes. Such an ideological development of the Chinese society among the younger generation also provided a flourishing soil for the legal awareness plan-section 3 subsection 2 provides that it aims to "strengthen education on the rule of law for young people", and "fully implement the 'Youth Rule of Law Education Syllabus', educate and guide young people to develop the habit of respecting and abiding by the law from an early age". As a result, for those youngsters who support such recall of the pure socialist spirit, it would be the ideological forces driving their obedience to the laws in China in the long run-including but not limited to laws covering the constitutional values of national sovereignty, and criminal law in general because the disobedience of which are in conflicts with their ideological beliefs.

\subsection{Summary of This Section}

This section shows that legal awareness can be regarded as a form of "soft power" - attracting and persuading individuals to voluntarily obey the laws. It shows that a powerful discourse of legal awareness would be engineered if three of the following are closely connected without conflicts: 1) the Law itself, 2) the external ideological environment, and 3) obedience of the laws. Thus, the author attempts to explain why the following three ideologies and social phenomena can be the driving force and motivations of the obedience of laws in the Chinese society-namely 1) the political atmosphere of anti-corruption 2) the political atmosphere of security, and 3) The recall of the socialist spirit. It, therefore, unmasks the second dynamics of the enhancement and continuance of legal awareness (obedience of the laws) in China-the ideological integration and coherence within the Chinese society. Such an ideological environment are the conditional social norms that the institutionalized norms (i.e. the laws) are attempting to engage with. One remark in this section is that, for the continuance and maintenance of legal awareness, such social dynamics would be largely dependent upon whether the integration discourses can support its development in the coming future-which implies that it depends on whether the obedience of the laws can give them additional meanings than the mere actions of doing so if not, there can be risks of social unrest or civil unrest as seen in some of the "democratic" societies across the globe which is largely the result of ideological conflicts (Cederman \& Pengl, 2019).

\section{Summary}

As shown from the above literature review, the concept "legal awareness" has been un-/consciously interpreted as carrying a "progressive" nature, meaning that it is one of the hallmarks of the architecture of a well-functioned legal system. Especially in the so-called "developing countries"-if this term is still using to denote non-Western countries in the global south-the institutionalization of social norms seems to be the central concern of both the local government and international institutions checkbox-alike parameters. This is not an indepen- 
dent/domestic phenomenon, but truly a global issue. The measurement of governance and Rule of Law has been connected with a powerful discourse of indicators and numerical analysis (Merry et al., 2015), "legal awareness", inter alia, has a huge potential to be adopted by these indicators as one of the measurements of a jurisdiction's judicial performance.

Yet, the underlying concerns are not whether such measurements can be an effective tool to generalize the welfare and collective interests of the society, but the implicit domination of foreign values that aims to "transform" the localized norms in the name of a better society. "In other words, instead of raising legal awareness by means of propaganda and public education, the authorities should lean more towards the substantial development of the legal system at large. The question of 'How to enhance legal awareness?' is not better than the questions of 'How to narrow down the socio-legal gap in society so that people are confident enough to seek Justice by the laws?', 'How to enhance the substantial socio-economic development so that people can make their decisions for the common good but not for survival?', and 'How to narrow down inequalities so that people are genuinely respecting the differences in race, gender, and sexuality instead of political-correctness or afraid of social stigmatization?"'. "Legal awareness" is neither a cure for legal illiteracy nor the recognition of the institutionalized laws. The discovery of legal culture outweighed the sociocultural imaginations of orders by the institutionalization of social norms.

\section{Acknowledgements}

The author is grateful to the editors at Beijing Law Review. All opinions and mistakes are solely those of the author.

\section{Conflicts of Interest}

The author declares no conflicts of interest regarding the publication of this paper.

\section{References}

Andreeva, O. A., Mordovtsev, A. Y., Shtompel, O. M., Timofeeva, A. A., \& Shuaipov, M. M. (2019). Legal Culture, Legal Worldview, and Legal Awareness of Subjects in Philosophical and Culturological Discourse. Journal of Politics and Law (Toronto), 12, 129. https://doi.org/10.5539/jpl.v12n5p129

Araújo, M., \& Maeso, S. (2014). The Politics of (Anti-)Racism. Academic Research and Policy Discourse in Europe. In W. D. Hund, \& A. Lentin (Eds.), Racism and Sociology-Racism Analysis. Yearbook 5 (pp. 207-237). LIT Verlag.

Baker McKenzie Client Alert (2019). China's Amended Trademark Law to Curb Bad Faith Filings.

https://www.bakermckenzie.com/en/insight/publications/2019/11/chinas-amended-tra demark-law

Baruzzi (2021). China's Copyright Law Amended: Key Changes.

https://www.china-briefing.com/news/china-copyright-law-amended-key-changes/

BBC (2020). Coronavirus Lockdown Protest: What's behind the US Demonstrations? 
BBC. https://www.bbc.com/news/world-us-canada-52359100

Blanchette, J. (2019). China's New Red Guards: The Return of Radicalism and the Rebirth of Mao Zedong (p. 3). Oxford University Press.

Bodenheimer, E. (1974). Jurisprudence: The Philosophy and Method of the Law (Rev. ed.). Harvard University Press.

Cederman, L.-R., \& Pengl, Y. (2019). Global Conflict Trends and Their Consequences. https://www.un.org/development/desa/dpad/wp-content/uploads/sites/45/publication/ SDO_BP_Cederman_Pengl.pdf

Chan, A. (2015). China's Migrant Workers' Legal Rights Awareness on the Rise. International Union Rights, 22, 6. https://doi.org/10.14213/inteuniorigh.22.4.0006

Charny, D. (1999). Farewell to an Idea? Ideology in Legal Theory. Michigan Law Review, 97, 1596-1616. https://doi.org/10.2307/1290221

Chawala, F. (2019). IB China-Anti-Corruption-Campaign 1. https://www.researchgate.net/publication/334645989_IB_china-anti-corruption-campa ign_1

Chen, J. Y. (2021). The Legal Protection for China's Flexible Workers during the COVID-19 Pandemic. Frontiers of Law in China, 16, 79-103.

China Daily (March 21, 2018). Chinese Democracy Proves Itself a Viable Alternative to West. China Daily. http://www.chinadaily.com.cn/a/201803/21/WS5ab1ac9fa3106e7dcc144041.html

Cowling, M. (2008). Would Communism Eliminate Crime? https://core.ac.uk/download/pdf/322325552.pdf

Deakin, S., Gindis, D., Hodgson, G. M., Huang, K., \& Pistor, K. (2016). Legal Institutionalism: Capitalism and the Constitutive Role of Law. Journal of Comparative Economics, 45, 188-200. https://doi.org/10.1016/j.jce.2016.04.005

Diallo, F. (April 9, 2021). Xi Jinping's Anti-Corruption Struggle. Issue Brief of Institute for Security \& Development Policy.

DiMatteo, L. A. (2018). "Rule of Law" in China: The Confrontation of Formal Law with Cultural Norms. Cornell International Law Journal, 51, Article 3. https://scholarship.law.cornell.edu/cilj/vol51/iss $2 / 3$

Douzinas, C. (2000). The End of Human Rights : Critical Legal Thought at the Turn of the Century. Hart Pub.

Eliasson, J. (December 5, 2015). Deputy Secretary-General, Marking Fiftieth Anniversary of Anti-Racism Convention, Urges Internet to Be Used as Powerful Tool in Fight against Racial Discrimination. Press Release.

https://www.un.org/press/en/2015/dsgsm921.doc.htm

Ewick, S., \& Patricia, S. (1998). The Common Place of Law: Stories from Everyday Life (p. 22). University of Chicago Press. https://doi.org/10.7208/chicago/9780226212708.001.0001

Feenan, D., Silbey, S. S., Clarke, J., Norrie, A., \& Minkkinen, P. (2013). Exploring the "Socio" of Socio-Legal Studies (Palgrave Macmillan Socio-Legal Studies) (p. 18, 115). Palgrave Macmillan Limited. https://doi.org/10.1007/978-1-137-31463-5

Fu, K. O. (2020). In the Context of Chinese Constitutionalism and the Hong Kong Basic Law: Is "Separation of Powers" a Delusionary Product? Tsinghua China Law Review, 13, 201-227.

Gabriel, B. (n.d.). What Are Socialist Values? https://classroom.synonym.com/what-are-socialist-values-12083768.html

Gal, D., Rucker, D. D., \& Shavitt, S. (2018). The Loss of Loss Aversion: Will It Loom Lar- 
ger Than Its Gain? Journal of Consumer Psychology, 28, 497-516.

https://doi.org/10.1002/jcpy.1047

Glueck (2020). Judging Criteria for Trademark Infringements.

https://cms.law/en/chn/publication/judging-criteria-for-trademark-infringements

He, X. (2021). Divorce in China: Institutional Constraints and Gendered Outcomes. New York University Press.

Hirsch, M., \& Lang, A. (2018). Research Handbook on the Sociology of International Law (Research Handbooks in International Law Series) (p. 99). Edward Elgar Publishing.

HK01 (May 8, 2021). Tsinghua University's Book Lending Ranking “Selected by Mao" Ranks First. Why Is Mao Zedong Sought after by Young People?

Hou et al. (2020). China: Mind The Gap-The IP Protection Law vs. Reality In China. https://www.mondaq.com/china/trademark/1010568/mind-the-gap--the-ip-protection -law-vs-reality-in-china

Hu, J. R. (2020). Labor Dispute Resolution and Migrant Workers' Legal Rights Protection in China. Chinese Journal of International Review, 2, Article ID: 2050004. https://doi.org/10.1142/S2630531320500043

Hunt, J. (June, 2012). A State-by-State Examination of Nondiscrimination Laws and Policies. Centre for American Progress Action Fund.

https://www.americanprogress.org/wp-content/uploads/issues/2012/06/pdf/state_nond iscrimination.pdf

Jones Day White Paper (2020). China Promulgates Fourth Amendment to Patent Law. https://www.jonesday.com/en/insights/2020/11/china-promulgates-fourth-amendment -to-patent-law

Jouannet, E. (2007). Universalism and Imperialism: The True-False Paradox of International Law? European Journal of International Law, 18, 379-407.

https://doi.org/10.1093/ejil/chm029

Kellner, D. (1981). A Bibliographical Note on Ideology and Cultural Studies. Praxis, 5, 84-88.

Khorakiwala, R. (2018). Legal Consciousness as Viewed through the Judicial Iconography of the Madras High Court. Asian Journal of Law and Society, 5, 111-133. https://doi.org/10.1017/als.2017.33

Kozhukhova, M., \& Zhiyenbayev, M. (2018). Conceptualizing Legal Culture and Legal Awareness: Meaning and Structural Components. SHS Web of Conferences, 55, Article ID: 02009 .

Krause, M. (2019). What Is Zeitgeist? Examining Period-Specific Cultural Patterns. Poetics, 76, Article ID: 101352. https://doi.org/10.1016/j.poetic.2019.02.003

LaCapra, D. (1988). Culture and Ideology: From Geertz to Marx. Poetics Today, 9, 377-394. https://doi.org/10.2307/1772695

Lai, H. (2016). China's Governance Model: Flexibility and Durability of Pragmatic Authoritarianism. Routledge. https://doi.org/10.4324/9781315832654

Laptev, V., \& Fedin, V. (2020). Legal Awareness in a Digital Society. Russian Law Journal, 8, 138-157. https://doi.org/10.17589/2309-8678-2020-8-1-138-157

Lau, J. (April 22, 2021). Corruption-Related Reports in Singapore Drop to 5-Year Low amid Covid-19 Pandemic. The Straits Times.

https://www.straitstimes.com/singapore/courts-crime/corruption-related-reports-drop -to-5-year-low-amid-covid-19

Lawrence, D., \& Patterson, J. (2018). FPC Briefing: Rule of Law in China: A Priority for Businesses and Western Governments. 
https://fpc.org.uk/wp-content/uploads/2018/09/FPC-Briefing-Rule-of-Law-in-China-S ep-2018.pdf

Liu, Q. (2018). Legal Consciousness of the Leftover Woman: Law and Qing in Chinese Family Relations. Asian Journal of Law and Society, 5, 7-27. https://doi.org/10.1017/als.2017.28

Liu, X., Zhang, Y., \& Vedlitz, A. (2021). Political Values and Life Satisfaction in China. The China Quarterly, 245, 276-291. https://doi.org/10.1017/S0305741020000272

Luo, C. F. (2018). Analysis on the Cultivation of Legal Consciousness of Higher Vocational Students. Educational Research, 1, 35.

Ma, K. (2018). College Students' Legal Awareness Cultivation and Education Based on the Characteristics of the New Era. Kuram ve Uygulamada Egitim Bilimleri, 18, 3456-3462.

Marshall, A.-M., \& Barclay, S. (2003). Introduction: In Their Own Words: How Ordinary People Construct the Legal World. Law \& Social Inquiry, 28, 617-628. https://doi.org/10.1111/j.1747-4469.2003.tb00209.x

Marx, K. (n.d.). A Contribution to the Critique of Political Economy. Project Gutenberg.

McGuire, K. T. (2004). The Institutionalization of the U.S. Supreme Court. Political Analysis, 12, 128-142. https://doi.org/10.1093/pan/mph005

Merry, S. E., Davis, K., \& Kingsbury, B. (2015). The Quiet Power of Indicators: Measuring Governance, Corruption, and Rule of Law. Cambridge University Press. https://doi.org/10.1017/CBO9781139871532

Morrison, W. M. (2019). China's Economic Rise: History, Trends, Challenges, Implications for the United States. RL33534 Congressional Research Services Report. https://fas.org/sgp/crs/row/RL33534.pdf

Na, L. (2009). Is There New Hope in Labor Rights Protection for Chinese Migrant Workers? Asian-Pacific Law \& Policy Journal, 10, 482.

Ng, K., \& Jacobson, B. (2017). How Global Is the Common Law? A Comparative Study of Asian Common Law Systems-Hong Kong, Malaysia, and Singapore. Asian Journal of Comparative Law, 12, 209-232. https://doi.org/10.1017/asjcl.2017.17

Nguten, T. P. (2018). Labour Law and (In)Justice in Workers' Letters in Vietnam. Asian Journal of Law and Society, 5, 29-47. https://doi.org/10.1017/als.2017.29

Nieto, E. P. (July 9, 2015). Law Is the Best Means of Transforming a Democratic Nation with Stability and Certainty: Enrique Peña Nieto. Gobierno de Mexico Blog. https://www.gob.mx/epn/en/articulos/law-is-the-best-means-of-transforming-a-democ $\underline{\text { ratic-nation-with-stability-and-certainty-enrique-pena-nieto-16272 }}$

Nye, J. S. (2004). Soft Power: The Means to Success in World Politics. Public Affairs.

Ong, J. (January 28, 2021). Singapore Ranked Third as Least Corrupt Country in the World, Top in Asia: Transparency International. The Star Times. https://www.straitstimes.com/singapore/politics/singapore-ranked-third-as-least-corru pt-country-in-the-world-top-in-asia

Peerenboom, R. (2002). China's Long March toward Rule of Law (p. 4). Cambridge University Press. https://doi.org/10.1017/CBO9780511493737

Powers, P. (2007). The Philosophical Foundations of Foucaultian Discourse Analysis. Critical Approaches to Discourse Analysis across Discipline, 1, 18-34.

Reuters (May 31, 2018). Singapore, Malaysia Working to Retrieve 1MDB Funds, Trace Witnesses. Reuters.

https://www.reuters.com/article/us-malaysia-politics-singapore/singapore-malaysia-wo rking-to-retrieve-1mdb-funds-trace-witnesses-idUSKCN1IW0PO 
Rosen, L. (2006). Law as Culture: An Invitation (Book Collections on Project MUSE) (p. 11). Princeton University Press. https://doi.org/10.1515/9781400887583

Sarayev, N., Antipova, N., \& Polyanichko, N. (2019). Regulatory and Pedagogical Aspects of the Formation of Anti-Corruption Legal Awareness in Educational Institutions. SHS Web of Conferences, 70, 11012. https://doi.org/10.1051/shsconf/20197011012

Shankar, A. C. (2020). 71\% of Malaysians View Government Corruption as a Big Problem, Says TI-M. The Edges Market.

https://www.theedgemarkets.com/article/71-malaysians-view-government-corruptionbig-problem-says-tim

Shanxi Fenyang City People's Procuratorate (2019). Research on the Current Situation of Legal Awareness of Contemporary College Students and Countermeasures. http://www.sxfenyang.jcy.gov.cn/llyt/201903/t20190304_2503343.shtml

Shi, Y. (November 28, 2019). Graphics: All You Need to Know about China's Rule of Law. CGTN.

https://news.cgtn.com/news/2019-11-28/Graphics-All-you-need-to-know-about-China -s-rule-of-law-LZpW0KeM8w/index.html

Somanawat, K. (2018). Constructing the Identity of the Thai Judge: Virtue, Status, and Power. Asian Journal of Law and Society, 5, 91-110. https://doi.org/10.1017/als.2017.32

Su, L. H.-L. (2018). Resistance, Evasion, and Inequality: Legal Consciousness of Intellectual Property Laws in Two Chinese Markets. Asian Journal of Law and Society, 5, 69-89. https://doi.org/10.1017/als.2017.31

Tan, K. P. (2012). The Ideology of Pragmatism: Neo-Liberal Globalisation and Political Authoritarianism in Singapore. Journal of Contemporary Asia, 42, 67-92. https://doi.org/10.1080/00472336.2012.634644

The Agency against Corruption (Taiwan, China) (2013). Investigation Report on the Integrity Business of the Governments of Singapore and Malaysia. https://www.aac.moj.gov.tw/media/57746/26193511615.pdf?mediaDL=true

Wang, J., \& Liu, S. (2019). Ordering Power under the Party: A Relational Approach to Law and Politics in China. Asian Journal of Law and Society, 6, 1-18. https://doi.org/10.1017/als.2018.40

Willig, C., \& Rogers, W. S. (2017). The SAGE Handbook of Qualitative Research in Psychology (2nd ed., p. 110). SAGE Publications Ltd.

https://doi.org/10.4135/9781526405555

Xinhua (2020). Financial Authorities'Regulatory Talks with Ant Group. http://en.people.cn/n3/2020/1228/c90000-9803453.html

Xinhua (2021). China Issues Plan on Building Rule of Law. http://www.xinhuanet.com/english/2021-01/10/c_139656578.htm

Xu, Z. M. (January 27, 2015). Are Chinese People's Lack of Legal Awareness Influenced by Traditional Culture? Tencent Culture. https://cul.qq.com/a/20150127/025064.htm

Yeung (2021). China: Seiko Awarded RMB 10 Million by Guangzhou Court. https://www.mondaq.com/china/trademark/1032414/seiko-awarded-rmb-10-million-b y-guangzhou-court

Zariski, A. (2014). Legal Literacy: An Introduction to Legal Studies. AU Press. https://doi.org/10.15215/aupress/9781927356449.01 